\title{
The Use of Multidimensional Exploration Techniques to Assess the Similarity of the Development Level of Energy Markets
}

\author{
Anna BLUSZCZ ${ }^{1)}$, Robert RANOSZ ${ }^{2}$
}

\begin{abstract}
1) dr hab. inż.; Silesian University of Technology, Faculty of Mining, Safety Engineering and Industrial Automation; email: anna.bluszcz@polsl.pl
${ }^{2)} \mathrm{dr}$ hab. inż., AGH University of Science and Technology, Faculty of Mining and Geoengineering, Department of Economics and

Management in Industry; email: rranosz@agh.edu.pl
\end{abstract}

http://doi.org/10.29227/IM-2020-01-74

Submission date: 16-01-2020 | Review date: 02-04-2020

\section{Abstract}

The article undertakes research in the field of analyzing the similarity of Member States in terms of parameters characterizing the level of development of energy markets. Internal energy integration within the European Union requires transformation of energy systems towards the production of ecological energy, which is a challenge for the economies of many countries. Therefore, the article shows a significant level of diversity in the energy markets of individual countries, which indicates the possibility of differentiating the set ecological goals to be achieved by 2030. Multidimensional analysis was used to select groups of similar countries. Data were collected for 2018 for nine diagnostic variables. The research resulted in six clusters of countries similar to each other in terms of the level of development of energy markets.

Keywords: energy markets, sustainable development, integrated markets, multidimensional comparative analysis, energy consumption

\section{Introduction}

The energy market is one of the most important sector of industry in European Union countries. Planning a longterm energy market strategy requires continuous analysis of the level of development of energy markets. Member States power industry are currently in the process of gradual integration that will take place in the long term. The structure of the European Union's energy balance is created by the Member States. This means that, despite common goals, the countries themselves decide on the direction of their individual policy. Therefore, the presentation of the energy situation in the EU is only possible due to the characteristics of individual national energy markets. The main goal of the article is to use multivariate analysis to examine the level of similarity between European Union countries in terms of energy markets. Nine diagnostic variables were selected as the variables characterizing the energy market such as: consumption of electric energy generated from renewables per capita (TWH/person), hard coal consumption (million tons/person), greenhouse gas emissions per capita, available for final consumption gigawatt-hour per person, final energy consumption thousand tons of oil equivalent (TOE) per person, petroleum available for final consumption (Gigawatt-hour), natural gas (Terajoule gross calorific value - GCV) per person, energy intensity of GDP (Kilograms of oil equivalent (KGOE) per thousand euro, import dependency \%. The analysis showed that the most important variable from the point of view of the division of countries is the energy dependence parameter.

The varied energy dependence between the members of the Community affects the overall direction of the strategy and actions taken by the EU in the energy sector.

Energy security is one of the basic elements that is a condition for ensuring each country's security and the possibility of sustainable and uninterrupted development. Currently, the importance of energy security is gaining additional weight because the demand for energy, energy resources and fuels is constantly growing. Energy security is a key aspect of building an integrated energy market.

One of the more frequently cited definitions of energy security was formulated by the American economic analyst $\mathrm{D}$. Yergin, according to which: the goal of energy security is to ensure an adequate and reliable level of energy supply at reasonable prices in a way that does not threaten the basic values and state goals [1].

The general energy security is the assurance that a nation receives the primary energy it needs for its economy and welfare. In theory, exist many definitions of energy security, but each of them tends to consider the issue of energy security only in one specific context.

The problem of energy security is an interdisciplinary concept that combines three perspectives at the same time, i.e., the energy, economic (market) and environmental perspective. The energy perspective includes the balancing of the demand and supply side, technical concept related to the technical infrastructure and its management and the diversification of deliveries of energy resources. The economic perspective is brought down to ensuring the acceptable price of energy resources, while the environmental one is related to ensuring the proper state of the natural environment for future generations [2].

According to the International Energy Agency (2014) energy security is defines as the uninterrupted availability of energy sources at an affordable price [3]. A standard definition of security of supply is a flow of energy supply to meet demand in a manner and at a price level that does not disrupt the course of the economy in an environmental sustainable manner. The concept is vast, multiform as it encompasses the whole physical and nonphysical supply chain. It has also 


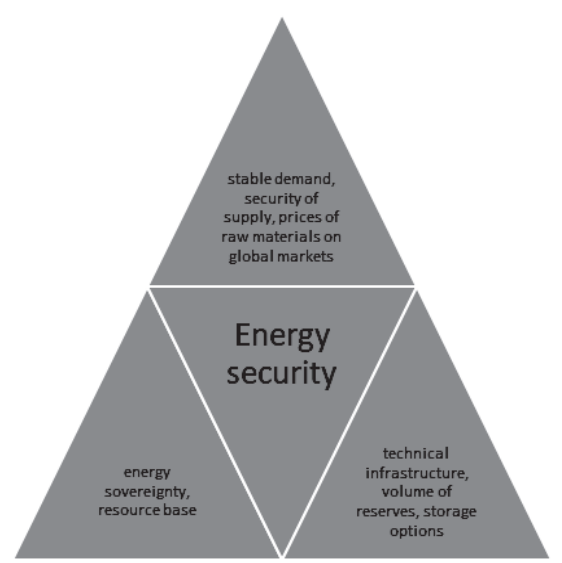

Fig. 1. Model of national energy security. Source: own elaboration

Rys. 1. Model krajowego bezpieczeństwa energetycznego. Źródło: opracowanie własne

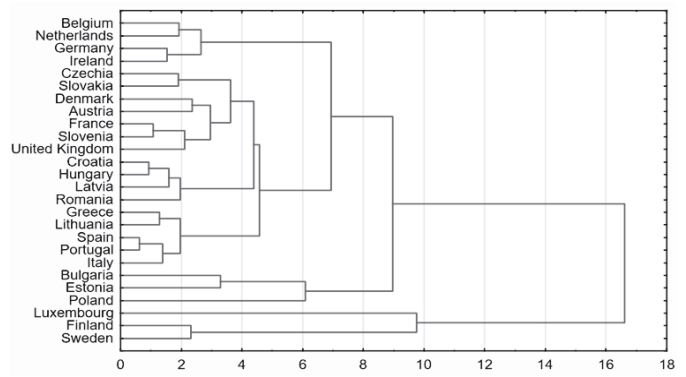

Fig. 2. Dendrogram for selected countries EU. Source: own elaboration

Rys. 2. Wykres dendrogramu dla wybranych państw UE. Źródło: opracowanie własne

important time, space and social dimensions. It can be more precisely defined as:

- A reliable supply of energy. Choices both for primary energy sources and geographical suppliers ought to be as plentiful as possible, within a competitive framework, in order to reduce dependence on only one or two. Diversification in these two areas - primary energy sources and suppliers - is key to ensuring security of supply.

- A reliable transportation of supply. Transportation networks ought to be physically available to qualified players, well maintained, and expanded as required, and should offer as many competitive route options as possible.

- A reliable distribution and delivery of supply to the final customer. Energy ought to be efficiently delivered to the final customer according to particular time and quality standard without discrimination.

- At "reasonable price" over a continuous period. In theory, "reasonable" price means marginal cost reflective [4].

Energy security has many aspects: long term energy security mainly deals with timely investments to supply energy in the line with economic developments and environmental needs. On the other hand, short-term energy security focuses on the ability of the energy system to react promptly to sudden changes in the supply-demand balance [3].

Member States' energy markets are currently in a process of continuous transformation towards integration within the European Union. The process of integrating the electricity market in Europe, although it started many years ago, still faces many technical and political obstacles. Although Member
States have declared that all European markets will be fully connected and coordinated by 2014 , the pace of integration is uneven. In western Europe, 75\% of the markets have already been integrated. In-depth analyzes are being carried out regarding joint balancing, connecting short-term markets and further improving the efficiency of the common energy market. During consultations on the new energy market structure launched by the European Commission in July 2015, ways of improving cooperation and coordination of energy policies at regional level were considered. The main motivation for actions for the integration of markets is to reduce energy prices, increase the possibilities of balancing energy systems due to the increase in the share of renewable energy sources (mainly unstable wind and solar sources) and to improve security of supply.

\section{Methodology and Data}

In the study, the k-means algorithm was used to assess the similarity in the level of development of energy markets in the Member States. The name of this method is derived from the representation of each cluster using the average or weighted average. In this method, the number of clusters are presumed a priori as well as the number of iterations. Algorithm for creating clusters is strongly dependent on the value of $\mathrm{k}$.

In the k-means method it is assumed $[5,6]$ that a set of $\mathrm{n}$ objects $\mathrm{D}=\left\{\mathrm{p}_{1}, \mathrm{p}_{2}, \ldots \mathrm{p}_{\mathrm{n}}\right\}$ is given. Each object $\mathrm{p}_{\mathrm{i}}=\left\{\mathrm{p}_{\mathrm{i} 1}, \mathrm{p}_{\mathrm{i} 2}, \ldots\right.$ $\mathrm{p}_{\mathrm{in}}$ \} represents a point of space $\mathrm{Rm}$, where $\mathrm{m}$ is the number of attributes that describe the objects of set $\mathrm{D}$ (the number of dimensions of space $\mathrm{Rm}$ ). Let $\mathrm{k}$ is a predetermined number of clusters, and mk the mean of cluster Ck. In the Eu- 
Tab. 1. Division into clusters of similar countries in terms of the level of development of energy markets. Source: own study Tab. 1. Podział na skupienia krajów podobnych pod względem rozwoju rynków energetycznych. Źródło: opracowanie własne

\begin{tabular}{|c|c|}
\hline Country & Distance \\
\hline \multicolumn{2}{|c|}{ Cluster 1} \\
\hline Finland & 0.385796 \\
\hline Sweden & 0.385796 \\
\hline \multicolumn{2}{|c|}{ Cluster 2} \\
\hline Poland & 0.000000 \\
\hline \multicolumn{2}{|c|}{ Cluster 3} \\
\hline Denmark & 0.769679 \\
\hline Greece & 0.397662 \\
\hline Spain & 0.376236 \\
\hline France & 0.328059 \\
\hline Croatia & 0.245432 \\
\hline Italy & 0.482352 \\
\hline Latvia & 0.498607 \\
\hline Lithuania & 0.450993 \\
\hline Hungary & 0.361465 \\
\hline Portugal & 0.386879 \\
\hline Romania & 0.660099 \\
\hline Slovenia & 0.380347 \\
\hline Slovakia & 0.533924 \\
\hline United Kingdom & 0.545045 \\
\hline \multicolumn{2}{|c|}{ Cluster 4} \\
\hline Belgium & 0.413261 \\
\hline Germany & 0.246645 \\
\hline Ireland & 0.502386 \\
\hline Netherlands & 0.557447 \\
\hline Austria & 0.564056 \\
\hline \multicolumn{2}{|c|}{ Cluster 5} \\
\hline Luxembourg & 0.000000 \\
\hline \multicolumn{2}{|c|}{ Cluster 6} \\
\hline Bulgaria & 0.612841 \\
\hline Czechia & 0.550646 \\
\hline Estonia & 0.616627 \\
\hline
\end{tabular}

clidean space, the mean of cluster is calculated according to formula:

$m_{k}=\frac{1}{\left|C_{k}\right|} \sum_{p_{i} \in C_{k}} p_{i}$

In the $\mathrm{k}$-means method the aim is to find the division of a set of objects $\mathrm{D}$ between the k clusters $\mathrm{C}_{1}, \mathrm{C}_{2}, \mathrm{C}_{\mathrm{k}}$, of means that minimizes the criterion function $\mathrm{e}(\mathrm{k})$ [7]. In the basic version of the algorithm the criterion function that is minimized, is the sum of the squared error [8, p. 153]:

$e(k)=\sum_{i=1}^{k} \sum_{p_{j} \in C_{i}} \operatorname{dist}\left(p_{j}, m_{i}\right)^{2}$

where:

$\mathrm{p}_{\mathrm{j}}$ - point in Rm space that represent object $\mathrm{pj}$,

$m_{i}-$ mean of cluster $C_{i}$,

$\operatorname{dist}\left(\mathrm{p}_{\mathrm{i}}, \mathrm{m}_{\mathrm{i}}\right)$ - Euclidean distance (norm L2) between object (point) $\mathrm{p}_{\mathrm{j}}$ and mean (centre) $\mathrm{mi}$ of the nearest cluster $\mathrm{C}_{\mathrm{i}}$.

Algorithm of the k-means analysis can be described by stages such as: A data set containing $\mathrm{n}$ objects is given and the number of clusters $\mathrm{k}$ is assumed.

1. Arbitrarily choose $\mathrm{k}$ objects from $\mathrm{D}$ as the initial cluster centers;

2. Repeat steps (a) and (b) until there are changes in the allocation of objects to clusters:

a) (re)assign each object pi $\in \mathrm{D}$ to the cluster $\mathrm{Ci}$, to which the object is most similar, based on the mean value of the objects pi in the cluster $\mathrm{Ci}$;

b) update the cluster means, i.e., calculate the mean value of the objects for each cluster.
A software Statistica of Statsoft was used in the calculations. K-means method has several advantages. It is relatively simple and the algorithm procedure is relatively efficient compared with hierarchical methods. The reasons for the algorithm's popularity are its ease of interpretation, simplicity of implementation, flexibility with regard to the accepted measure of distance.

\section{Results}

For the comparative analysis of the level of development of energy markets in the European Union, nine diagnostic variables were selected, such as: consumption of electric energy generated from renewables per capita (TWH/person), hard coal consumption (million tons/person), greenhouse gas emissions per capita, available for final consumption gigawatt-hour per person, final energy consumption thousand tons of oil equivalent (TOE) per person, petroleum available for final consumption (Gigawatt-hour), natural gas (Terajoule gross calorific value - GCV) per person, energy intensity of GDP (Kilograms of oil equivalent (KGOE) per thousand euro, import dependency \%. Data for analysis are available in the Eurostat database. The first stage of preparing data for calculations is the data standardization process, which means that the variables expressed in different units are expressed dimensionless. The standardization and calculation process was performed in the Statistica software. Cluster analysis was performed for 26 European Union member states for 2018 (Cyprus and Malta were omitted due to a negligible share in energy production). The second stages in the analysis was the decision to indicate the parameter $\mathrm{k}$ - the number of clusters. For this purpose, another grouping method called the 
Tab. 2. Average values for standardized data for selected clusters. Source: own study

Tab. 2. Średnie wartości dla znormalizowanych danych dla wyselekcjonowanych skupień. Źródło: opracowanie własne

\begin{tabular}{|l|c|c|c|c|c|c|}
\hline Diagnostic variables/clusters & Cluster 1 & Cluster 2 & Cluster 3 & Cluster 4 & Cluster 5 & Cluster 6 \\
\hline $\begin{array}{l}\text { consumption of electric energy } \\
\text { generated from renewables per capita } \\
\text { (TWH/person) }\end{array}$ & 2.69242 & -0.779286 & -0.309350 & -0.189163 & 1.413013 & -0.24728 \\
\hline $\begin{array}{l}\text { hard coal consumption } \\
\text { (million tons/person) }\end{array}$ & 0.41053 & 3.836193 & -0.355363 & 0.299077 & -0.408575 & -0.25633 \\
\hline $\begin{array}{l}\text { Greenhouse gas emissions } \\
\text { per capita }\end{array}$ & -0.43408 & 0.478982 & -0.596589 & 0.580765 & 3.173254 & 0.88811 \\
\hline $\begin{array}{l}\text { Available for final consumption } \\
\text { Gigawatt-hour per person }\end{array}$ & 1.93314 & -0.700995 & -0.457153 & 0.099236 & 3.464991 & -0.24210 \\
\hline $\begin{array}{l}\text { Final energy consumption } \\
\text { Thousand tons of oil equivalent } \\
\text { (TOE) per person }\end{array}$ & 0.51966 & -0.410068 & -0.348960 & 0.102128 & 4.629009 & -0.29449 \\
\hline $\begin{array}{l}\text { Petroleum available } \\
\text { for final consumption Gigawatt-hour }\end{array}$ & 1.93314 & -0.700995 & -0.457153 & 0.099236 & 3.464991 & -0.24210 \\
\hline $\begin{array}{l}\text { Natural gas Terajoule } \\
\text { (gross calorific value - GCV) per } \\
\text { person }\end{array}$ & -1.01848 & -0.706558 & -0.238848 & 0.966565 & 3.094710 & -0.61338 \\
\hline $\begin{array}{l}\text { Energy intensity of GDP } \\
\text { Kilograms of oil equivalent (KGOE) } \\
\text { per thousand euro }\end{array}$ & -0.22769 & 0.751728 & -0.141829 & -0.683686 & -0.929565 & 2.01242 \\
\hline Import dependency\% & -0.77105 & -0.414164 & 0.064658 & 0.635332 & 1.906116 & -1.34391 \\
\hline
\end{tabular}

Tab. 3. Analysis of variance. Source: own study

Tab. 3. Analiza wariancji. Źródło: opracowanie własne

\begin{tabular}{|l|c|c|c|c|c|c|}
\hline Variables & $\begin{array}{c}\text { Between } \\
\text { SS }\end{array}$ & df & Inside SS & df & F & $\begin{array}{c}\text { Significance } \\
\text { p }\end{array}$ \\
\hline $\begin{array}{l}\text { consumption of electric energy } \\
\text { generated from renewables per capita } \\
\text { (TWH/person) }\end{array}$ & 18.80426 & 5 & 6.19574 & 20 & 12.1401 & 0.000017 \\
\hline $\begin{array}{l}\text { hard coal consumption } \\
\text { (million tons/person) }\end{array}$ & 17.63268 & 5 & 7.36732 & 20 & 9.5735 & 0.000088 \\
\hline $\begin{array}{l}\text { Greenhouse gas emissions } \\
\text { per capita }\end{array}$ & 19.71134 & 5 & 5.28866 & 20 & 14.9084 & 0.000004 \\
\hline $\begin{array}{l}\text { Available for final consumption } \\
\text { Gigawatt-hour per person }\end{array}$ & 23.12252 & 5 & 1.87748 & 20 & 49.2628 & 0.000000 \\
\hline $\begin{array}{l}\text { Final energy consumption } \\
\text { Thousand tons of oil equivalent (TOE) per person }\end{array}$ & 24.15311 & 5 & 0.84689 & 20 & 114.0797 & 0.000000 \\
\hline $\begin{array}{l}\text { Petroleum available } \\
\text { for final consumption Gigawatt-hour }\end{array}$ & 23.12252 & 5 & 1.87748 & 20 & 49.2628 & 0.000000 \\
\hline $\begin{array}{l}\text { Natural gas Terajoule } \\
\text { gross calorific value - GCV) per person }\end{array}$ & 18.74968 & 5 & 6.25032 & 20 & 11.9992 & 0.000018 \\
\hline $\begin{array}{l}\text { Energy intensity of GDP } \\
\text { Kilograms of oil equivalent (KGOE) per thousand } \\
\text { euro }\end{array}$ & 16.30109 & 5 & 8.69891 & 20 & 7.4957 & 0.000417 \\
\hline Import dependency \% & 12.48890 & 5 & 12.51110 & 20 & 3.9929 & 0.011271 \\
\hline
\end{tabular}

agglomeration was used. The agglomeration process is presented in the figure 2 in the form of a chart dendrogram. In the agglomeration process, the Ward method was used, which uses variance analysis to estimate the distance between clusters. Based on the analysis of the dendrogram, it is possible to read the indication of the parameter $k$, i.e. the number of clusters. The decision on the number of clusters depends on the authors of the study, who decided about the degree of detail made by the division.

Based on the analysis of the dendrogram, the decision was made to group objects using the k-means method into 6 clusters. The results of the division of Member States by nine examined variables characterizing the level of development of energy markets are presented in Table 1.

On the basis of the presented average analysis for data subject to standardization, the resulting groups of similar countries can be characterized as follows. Cluster 1 has the highest level of use of renewable sources for energy production. Cluster 2, in which Poland is located as the only element of concentration, is characterized by the highest level of coal use in the energy production structure. This variable is so different compared to other countries that it determines the division into a separate one-element cluster. Hard coal, due to its rich deposits, is and will be the basic energy source in the country in the next decade $[9,10,11,12,13]$. Hard coal mining in Poland has been undergoing restructuring for many years in order to adapt the business structure and economic efficiency to the current market requirements $[14,15,16]$. Coal mine companies take steps aimed at improving management processes by rationalizing the internal processes and introducing tools to support the implementation of their strategies $[17,18]$. It also becomes necessary for them to use various types of measurement systems to monitor achievements of the strategic goals the form of key performance indicators [19]. Among them, environmental goals are pivotal in reducing greenhouse gas emissions. They are the biggest challenge for the mining industry, which is accompanied by changes in energy systems $[20,21$, 22, 23, 24].

Cluster number 3 is characterized by a relatively low level of average GHG emissions per capita and a high level of import dependence. Cluster number 4 contains countries with high levels of per capita emissions. On the other hand, the level of emissions for Luxembourg is the highest in the Member States, which determines the division of this country into separate cluster number 5 .

Cluster number 6 , on the other hand, contains countries with a high level of energy intensity. 
Based on the analysis of variance, it can be concluded that the most important variable for the division of data into groups was import dependency.

\section{Discussion and Conclusions}

The cluster analyzes presented in the article are a significant tool to organize and group data. Hierarchical and non-hierarchical methods used to classify Member States into six similar groups in terms of the level of development of energy markets. The energy policy of the member states requires that all member states should achieve the same ecological goals by 2030 such as:

- $40 \%$ reduction in greenhouse gas emissions compared to 1990 emissions,
- $\quad$ at least $32 \%$ share of renewable sources in gross final energy consumption,

- $\quad$ increase in energy efficiency by $32.5 \%$.

The article presents the diversity of Member States' energy markets, which would allow for the introduction of differentiation in terms of possibilities to meet stringent environmental goals for groups of countries similar in terms of the level of development of energy markets.

The scientific problem presented in the article is only an example of algorithm that can be used in practice and does not exhaust the complex topic of comparing the energy markets of member countries.

\section{Literatura - References}

1. Yergin D.: Energy security in the 1990s, Foreign Affairs, 1998. No 1.

2. Bluszcz A.: European Economies in terms of energy dependence. Quality and Quantity 2017, vol.51. no. 4 15311548. DOI 10.1007/s11135-016-0350-1

3. Chevalier, J.M.: Security of energy supply for European Union. European Review of Energy Markets 2006, 1(3), pp. 1-20. https://www.eeinstitute.org/european-review-of-energy-market/EREM\%203\%20article\%20Jean-Marie\%20 Chevalier.pdf.

4. IEA-International Energy Agency Energy Supply Security, emergency response of IEA countries. 2014.

5. Morzy T.: Exploration of data. Methods and Algorithms. PWN Warsaw, 2013.

6. Stanisz A.: Accessible statistics course using STATISTICA PL with examples from medicine. T. 3. Multivariate Analyses. Krakow, 2007.

7. Likas A., Vlassis N., Verbeek J.J.: The global k-means clustering algorithm. Pattern Recognition 2003, 36(2), 451461. http://doi.org/10.1016/S0031-3203(02)00060-2

8. Larose D.T.: Discovering Knowledge in Data. Introduction to Data Mining. Hoboken, John Wiley \& Sons, Inc. New Jersey, 2005.

9. Ranosz R.: Mining and its importance in the global economy. Mineral Resources Management 2014, 30 (1), 5-20. http://doi.org/10.2478/gospo-2014-0003

10. Jonek-Kowalska I.: Challenges for long-term industry restructuring in the Upper Silesian Basin. What has Polish coal mining achieved and failed from a twenty - year perspective? Resource Policy 2015, 44(C),135-149.

11. Bąk P., Sukiennik M.: Impact of corporate culture on business goals of Energy Sector Companies. SEED 2017 International conference on the Sustainable Energy and Environment Development: Institute for Sustainable Energy 2017, p. 3.

12. Brzychczy E.: An overview of data mining and process mining applications in underground mining. Inżynieria Mineralna 2019, R.21 nr 1,pp. 301-314.

13. Kowal B., Kustra A.: Sustainability reporting in the energy sector, E3S Web of Conferences 2016, 10, 00129.

14. Manowska A, Nowrot A.: The importance of heat emission caused by global energy production in terms of climate impact. Energies 2019, vol. 12 iss. 16, 1-12. https://doi.org/10.3390/en12163069.

15. Ranosz R.: Analysis of the structure and cost of capital in mining enterprises. Mineral Resources Management 2017, ISSN 0860-0953. vol. 33 iss. 1, 77-91.

16. Dubiński, J., Turek, M.: Chances and threats of hard coal mining development in Poland - the results of experts research. Archives of Mining Sciences 2014, 59 (2), 395-411. http://doi.org/10.2478/amsc-2014-0028.

17. Kowal, B., Ranosz, R., Karkula, M., Kowal, D. Process Management in Hard Coal Mining Companies, Journal of the Polish Mineral Engineering Society 2018, iss. 2 (42), 111-116, http://doi.org/10.29227/IM-2018-02-14. 
18. Kowal, B.; Bąk, P.; Sukiennik, P. Dashboard - a system of measures supporting the enterprise in achieving its goals, Journal of the Polish Mineral Engineering Society 2018, iss. 2 (42), 41-46, http://doi.org/10.29227/IM-2018-02-14.

19. Kowal, B. Key performance indicators in a multi-dimensional performance card in the energy sector, E3S Web of Conferences 2019, ISSN 1755-1307, IOP Conf. Ser.: Earth Environ. Sci. 214 012093, 1-6.

20. Bluszcz A.: European Economies in terms of energy dependence. Quality and Quantity 2017, vol.51. no. 4 15311548.. https://doi.org/1007/s11135-016-0350-1.

21. Bluszcz A.: The emissivity and energy intensity in EU countries - consequences for the Polish economy. Conference proceedings Energy and clean technologies. Recycling, air pollution and climate change Sofia 2018, STEF92 vol. 18, iss. 4.2, 631-638. https://doi.org// 10.5593/sgem2018/4.2/S19.081.

22. Kijewska A., Bluszcz A.: Analysis of greenhouse gas emissions in the European Union with the use of agglomeration algorithm. Journal of Sustainable Mining 2016a. Vol. 15 iss.4 133-142 DOI 10.1016/j.jsm.2017.02.001

23. Kijewska A., Bluszcz A.: Research of varying levels of greenhouse gas emissions in European countries using the k-means method. Atmospheric Pollution Research 2016b, Vol. 7 iss. 5, s. 935-944. DOI 10.1016/j.apr.2016.05.010

24. Grabowska S.: Improvement of the heat treatment process in the industry 4.0 context. METAL 2018. 27th International Conference on Metallurgy and Materials, Conference proceedings. Tanger Ostrava 2018, 1985-1990.

\section{Wykorzystanie wielowymiarowych technik eksploracyjnych do oceny podobieństwa poziomu rozwoju rynków energii}

$W$ artykule podjęto badania $w$ zakresie analizy podobieństwa państw członkowskich pod względem parametrów charakteryzujących poziom rozwoju rynków energetycznych. Integracja wewnętrza energetyki w ramach Unii Europejskiej wymaga transformacji systemów energetycznych w kierunku wytwarzania energii ekologicznej, co stanowi wyzwanie dla gospodarek wielu krajów. Dlatego w artykule wykazano znaczący poziom zróżnicowania rynków energetycznych poszczególnych państw, co wskazuje na możliwość zróżnicowania wyznaczonych celów ekologicznych do osiagnięcia w perspektywie do 2030 roku. Wykorzystano analizę wielowymiarowa do wyselekcjonowania grup państw podobnych. Dane zebrano dla 2018 roku dla dziewięciu zmiennych diagnostycznych. W wyniku badań uzyskano sześć skupień państw podobnych do siebie pod względem poziomu rozwoju rynków energetycznych.

Słowa kluczowe: rynki energetyczne, zrównoważony rozwój, analiza wielowymiarowa, konsumpcja energii 